\title{
Motivasi Berprestasi, Kepuasan Kerja dan Manajerial Kepala Sekolah serta Dampaknya terhadap Kinerja Guru
}

\author{
Rita Sari* \\ Fakultas TIK, Institut Agama Islam Negeri Langsa, Indonesia \\ Diterima: Oktober 2018; Disetujui: Oktober 2018; Dipublish: Oktober 2018 \\ *Coresponding Email: ritasari17@iainlangsa.ac.id
}

\begin{abstract}
Abstrak
Tujuan penelitian ini adalah untuk mengetahui dampak variabel bebas (motivasi berprestasi, kepuasan kerja, dan manajerial kepala sekolah) terhadap variabel terikat (kinerja guru). Penelitian dilaksanakan pada SD Negeri 7 Idi Kabupaten Aceh Timur dengan melibatkan 30 orang responden. Kuesioner dipilih sebagai instrumen penelitian. Hasil analisis data menunjukkan bahwa (1) secara parsial, variabel bebas motivasi berprestasi memiliki dampak yang positif terhadap kinerja guru (thitung = 4,86 > ttabel = 2,36); (2) variabel bebas kepuasan kerja juga berdampak positif terhadap kinerja guru (thitung = 3,20 > ttabel $=2,36$ ); (3) variabel bebas manajerial kepala sekolah turut serta memberikan dampak positif terhadap kinerja guru (thitung $=3,21>$ ttabel $=2,36$ ); $(4)$ secara simultan, variabel bebas tidak memberikan dampak yang signifikan terhadap kinerja guru (Fhitung $=2,00<$ Ftabel = 2,92); dan (5) diperoleh persamaan regresi $Y=7,71 \mathrm{a}+0,02 \mathrm{X} 1+0,33 \mathrm{X} 2+0,26 \mathrm{X} 3$ artinya bahwa apabila ada peningkatan motivasi berprestasi, kepuasan guru, dan manajerial kepala sekolah maka secara otomatis akan meningkatkan kinerja guru.

Kata Kunci: Motivasi Berprestasi, Kepuasan Kerja, Manajerial Kepala Sekolah, Kinerja Guru.
\end{abstract}

\begin{abstract}
Purpose of this research is to know the impact of the independent variable (achieving motivation, job satisfaction, and managerial principal) toward of dependent variable (teachers's performance). The research was conducted on SD Negeri 7 Idi East Aceh with 30 respondents. The questionnaire was selected as a research instrument. The results of the analysis of the data indicates that (1) partially, independent variables of achieving motivation have a positive impact on teachers's performance $(t=4.86>$ ttable $=$ 2.36); (2) the independent variable (achieving motivation, job satisfaction, and managerial principal of job satisfaction also positively impact on teachers's performance $(t=3.20>$ ttable $=2.36)$; (3) the principal managerial independent variables take part give a positive impact on performance guru $(t=3.21>$ ttable = 2.36); (4) the simultaneous, independent variables does not give a significant impact on teachers's performance $(F=2.00<$ Ftable $=2.92)$; and (5) were obtained the equations of the regression of $Y=7,71 a$ $+0,02 X 1+0,33 X 2+0,26 X 3$ it means that when there is an increase in the motivation of overachievers, the satisfaction of teachers, and the principal managerial it will automatically improve the performance of teachers.
\end{abstract}

Keywords: Youth Role, Ecotourism Management, Tangkahan Tourisme Institute

How to Cite: Sari, R. (2018). Motivasi Berprestasi, Kepuasan Kerja dan Manajerial Kepala Sekolah serta Dampaknya terhadap Kinerja Guru. Journal of Education, Humaniora and Social Sciences (JEHSS). 1 (1): 16-19.

\section{PENDAHULUAN}

Guru merupakan pemimpin pembelajaran, sebab gurulah yang menentukan mutu pendidikan dan akan berimplikasi pada kualitas output pendidikan. Kinerja guru merupakan unjuk kerja yang ditampilkan dalam melaksanakan tugasnya sebagai pendidik.

Kinerja guru menjadi hal yang selalu hangat untuk didiskusikan, sebab dinilai tidak optimal. Guru terkesan melaksanakan tugas hanya sebagai rutinitas sehingga inovasi dan kreativitasnya tertutup. Apabila ada guru yang mengembangkan kreativitasnya maka cenderung dinilai membuang-buang waktu saja.

Hal tersebut diperkuat dengan pendapat Sagala (2011) yang mengemukakan bahwa hasil penataran guru pada berbagai bidang studi belum menunjukkan daya kerja berbeda dibanding kinerja guru yang tidak mengikuti penataran. Tidak ada kontrol terhadap hasil penataran meski penataran itu telah menghabiskan biaya cukup besar.

Kinerja (performance) dapat dimaknai sebagai tindakan menampilkan suatu kegiatan atau aktivitas. Mangkunegara (2009) menjelaskan bahwa kinerja (prestasi kerja) adalah hasil kerja secara kualitas dan kuantitas yang dicapai oleh seseorang pegawai dalam melaksanakan tugasnya sesuai dengan tanggung 
jawab yang diberikan kepadanya. Suharputra (2013) menambahkan bahwa kinerja merupakan suatu kemampuan kerja atau prestasi kerja yang diperlihatkan oleh seorang pegawai untuk memperoleh hasil kerja yang optimal. Sehingga dapat disimpulkan bahwa kinerja adalah upaya yang dilakukan oleh seseorang untuk mencapai tujuan tertentu sesuai dengan standar yang telah ditetapkan.

Teori atribusi dapat digunakan untuk menjelaskan penyebab-penyebab dibalik kinerja guru dengan akurat. Menurut Timpe (2002) teori atribusi didasarkan pada asumsi bahwa orang cenderung tidak merasa puas dengan hanya mengetahui apa yang dikerjakan orang, tetapi suka mencari-cari alasan mengapa mereka melakukannya. Keinginan untuk memahaminya ini adalah suatu keinginan yang sehat yang menerapkan analisis penyebab perilaku mereka sendiri serta perilaku-perilaku orang lain.

Terdapat dua kategori dasar atribusi yang bersifat internal atau disposisional (dihubungkan dengan sifat-sifat orang) dan yang bersifat eksternal atau situasional (yang dapat dihubungkan dengan lingkungan seseorang). Kedua kategori tersebut divisualisasikan melalui tabel 1. di bawah ini:

\begin{tabular}{lll}
\hline \multicolumn{2}{l}{ Mengapa dibalik keberhasilan dan kegagalan } & \\
& Internal (pribadi) & Eksternal (lingkungan) \\
\hline Kinerja baik & Kemampuan tinggi & Pekerjaan mudah \\
& Kinerja keras & Nasib baik \\
& & Bantuan dari rekan-rekan kerja \\
& & Pimpinan yang baik \\
Kinerja jelek & Kemampuan rendah & Pekerjaan sulit \\
& Upaya sedikit & Nasib buruk \\
& & Rekan-rekan kerja tidak produktif \\
& & Pimpinan yang tidak simpatik \\
\hline
\end{tabular}

Tabel 1. Faktor Atribusi Kinerja

Dari tabel 1 di atas, dapat dijelaskan bahwa kinerja merupakan akumulasi dari tiga aspek, yaitu (1) keterampilan; (2) upaya; dan (3) sifat-sifat eksternal. Keterampilan sangat diperlukan dalam kinerja karena merupakan aktivitas yang muncul dari seseorang akibat dari proses pengetahuan, kemampuan, kecakapan interpersonal, dan kecakapan teknis.

Upaya dapat digambarkan sebagai motivasi yang diperlihatkan seseorang dalam menyelesaikan pekerjaan. Sementara sifat-sifat eksternal adalah fasilitas dan lingkungan kerja yang mendukung kinerja, seperti sumber daya, struktur pekerjaan, imbalan, dan kepemimpinan (manajerial).

Motivasi dipahami sebagai proses untuk memberi semangat, arah, dan kegigihan perilaku. Hal yang harus diingat bahwa motivasi tidak dapat dipaksakan. Motivasi itu harus muncul dari diri sendiri, bersifat individual, sengaja, dan bersegi banyak.

Mangkunegara (2009) mengemukakan bahwa motivasi terbentuk dari sikap seseorang dalam menghadapi situasi kerja. Motivasi merupakan kondisi yang mengerakkan diri yang terarah untuk mencapai tujuan organisasi. Guru akan mampu mencapai kinerja maksimal jika ia memiliki motivasi tinggi.

Faktor mendasar terkait dengan kinerja adalah kepuasan kerja yang berhubungan dengan kesejahteraan. Kepuasan kerja dilatarbelakangi oleh: (a) imbalan jasa; (b) rasa aman; (c) pengaruh antarpribadi; (d) kondisi lingkungan kerja; dan (e) kesempatan untuk pengembangan dan peningkatan diri.

Teori Maslow menjelaskan bahwa kebutuhan yang paling rendah guna memenuhi adalah kebutuhn fisiologis seperti pangan, sandang, dan papan. Rasa aman merupakan kebutuhan kedua setelah kebutuhan pertama terpenuhi. Pengaruh antarpribadi disebut juga sebagai kebutuhan sosial yang berada pada hirarki ketiga. Kesempatan untuk berkembang adalah kebutuhan keempat. Terakhir adalah kebutuhan untuk meningkatkan diri atau aktualisasi diri sebagai kebutuhan kelima dari bawah.

Robbins dan Judge (2008) mengartikan kepuasan kerja sebagai sikap umum individu terhadap pekerjaannya. Sikap individu bisa menyangkut puas dan tidak puas pada seluruh dimensi dari pekerjaannya. Sementara Husaini Usman (2011) menguraikan bahwa kepuasan kerja adalah sikap seseorang terhadap pekerjaannya yang mencerminkan pengalaman yang menyenangkan dan tidak menyenangkan dalam pekerjaannya serta harapan-harapannya terhadap pengalaman masa depan. Jadi dapat dikatakan bahwa kepuasan kerja reaksi personal dalam melaksanakan tugasnya ditempat kerja.

Sekolah sebagai sebuah organisasi pendidikan tentunya memiliki pemimpin yang idealnya harus dipatuhi dan disegani oleh bawahannya. Organisasi tanpa pemimpin akan kacau balau. Peranan kepala sekolah sebagai pemimpin pendidikan antara lain sebagai educator, manager, administrator, supervisor, leader, inovator, dan motivator. 
Sebagai educator, kepala sekolah berperan merencanakan, melaksanakan, menilai hasil pembelajaran, membimbing dan melatih, meneliti dan mengabdi kepada masyarakat. Sebagai manager, kepala sekolah melakukan perencanaan, pengorganisasian, pengarahan, dan pengawasan. Sebagai administrator, maka ia harus mampu mengelola ketatausahaan sekolah dalam mendukung pencapaian tujuan sekolah. Sebagai supervisor, kepala sekolah harus mampu merencanakan program supervisi akademik dalam rangka peningkatan profesionalisme guru, melaksanakan supervisi akademik terhadap guru dengan menggunakan pendekatan dan teknik supervisi yang tepat, dan menindaklanjuti hasil supervisi akademik terhadap guru dalam rangka peningkatan profesionalisme guru.

Sebagai leader, kepala sekolah harus mampu memimpin sekolah dalam rangka pendayagunaan sumber daya sekolah secraa optimal. Sebagai inovator, kepala sekolah harus mampu mencari gagasan baru untuk pembaharuan sekolah, bekerja keras, mampu memasarkan sekolah agar siswanya banyak dan naluri kewirausahaan. Dan terakhir sebagai motivator, maka kepala sekolah harus mampu membangkitkan semangat, mengatur lingkungan kerja fisik, mengatur suasana kerja (iklim sekolah) yang kondusif, serta memiliki kemampuan menerapkan prinsip penghargaan dan hukuman.

Jadi jelaslah sudah bahwa kinerja guru sangat dipengaruhi motivasi berprestasinya, kepuasan kerja, dan manajerial kepala sekolah dalam memimpin sekolah. Sehingga dengan keterkaitan seperti yang telah dijelaskan di atas, maka perlu dilakukan sebuah studi mengenai motivasi berprestassi, kepuasan kerja, dan manajerial kepala sekolah serta dampaknya terhadap kinerja guru di SD Negeri 7 Idi Kabupaten Aceh Timur. Studi ini diharapkan memberikan informasi mengenai pentingnya pengembangan kinerja guru.

\section{METODE PENELITIAN}

Penelitian ini menggunakan pendekatan kuantitatif dengan format deskriptif. Bungin (2013) mengungkapkan bahwa penelitian deskriptif bertujuan untuk menjelaskan, meringkaskan berbagai kondisi, berbagai situasi, atau berbagai variabel yang timbul di masyarakat yang menjadi objek dari penelitian itu berdasarkan apa yang terjadi. Kemudian mengangkat ke permukaan karakter atau gambaran tentang kondisi, situasi, ataupun variabel tersebut.

Jenis penelitian menggunakan rancangan survei. Menurut Creswell (2015) rancangan penelitian survei adalah prosedur dalam penelitian kuantitatif dimana peneliti mengadministrasikan survei pada suatu sampel atau pada seluruh populasi orang untuk mendeskripsikan sikap, pendapat, perilaku, atau ciri khusus populasi.

Bentuk rancangan survei yang paling populer digunakan dibidang pendidikan adalah rancangan survei cross sectional design. Dalam cross sectional design, peneliti akan mengumpulkan data pada satu titik waktu tertentu.

Penelitian dilakukan pada SD Negeri 7 Idi Kabupaten Aceh Timur terhadap 30 orang sampel penelitian. Teknik pengumpul data yang digunakan adalah menyebarkan kuesioner motivasi berprestasi, kuesioner kepuasan kerja, kuesioner manajerial kepala sekolah, dan kuesioner kinerja guru.

Teknik analisis data yang digunakan adalah dengan melakukan (1) uji asumsi klasik dan (2) uji hipotesis regresi linier berganda. Pengolahan data penelitian dilakukan dengan menggunakan software SPSS versi 22.0 .

\section{HASIL DAN PEMBAHASAN \\ Deskripsi Kuesioner Penelitian}

Hasil analisis kuesioner untuk variabel bebas motivasi berprestasi $\left(\mathrm{X}_{1}\right)$ guru yang diberikan kepada 30 orang guru sebagai responden diperoleh hasil $80,17 \%$ artinya motivasi berprestasi guru di SD Negeri 7 Idi berada dalam kategori sangat tinggi.

Sementara analisis kuesioner kepuasan kerja $\left(\mathrm{X}_{2}\right)$ 75,42\% termasuk pada kategori puas. Berdasarkan hasil analisis data kuesioner bahwa manajerial kepala sekolah $\left(\mathrm{X}_{3}\right)$ termasuk pada kategori sangat baik yakni $80,83 \%$.

Analisis terhadap kuesioner variabel terikat kinerja guru $(Y)$ memberikan hasil sebesar 72,25\% atau kinerja guru di SD Negeri 7 Idi berada pada kategori cukup.

\section{Deskripsi Hipotesis Penelitian}

Seluruh data penelitian telah melalui uji asumsi klasik dan hasilnya menunjukkan bahwa model regresi penelitian ini layak untuk dipredikasi karena uji asumsi klasik terpenuhi. Lima uji asumsi klasik yang dilakukan adalah; (1) uji multikolinieritas, (2) uji normalitas, (3) uji heterokedastisitas, (4) uji autokorelasi, dan (5) uji linieritas.

Uji hipotesis dilakukan dengan menguji secara parsial, secara simultan, dan dilanjutkan dengan uji regresi ganda. Maka hasil yang diperoleh adalah sebagai berikut:

1. Uji Parsial (Uji t) 
a. Diperoleh nilai $t_{\text {hitung }}=4,86>$ tabel $=2,36$ maka Ho ditolak dan Ha diterima sehingga motivasi $\left(\mathrm{X}_{1}\right)$ memiliki dampak yang positif terhadap kinerja guru $(\mathrm{Y})$.

b. Diperoleh nilai $t_{\text {hitung }}=3,20>t_{\text {tabel }}=2,36$ sehingga Ho ditolak dan Ha diterima artinya kepuasan kerja $\left(\mathrm{X}_{2}\right)$ memiliki dampak positif terhadap kinerja guru $(\mathrm{Y})$.

c. Diperoleh nilai thitung $=3,21>t_{\text {tabel }}=2,36$ artinya Ho ditolak dan Ha diterima dapat disimpulkan bahwa manajerial kepala sekolah $\left(\mathrm{X}_{3}\right)$ memberikan pengaruh positif terhadap kinerja guru $(\mathrm{Y})$.

2. Uji Simultan (Uji F)

Diperoleh nilai $\mathrm{F}_{\text {hitung }}=2,00<\mathrm{F}_{\text {tabel }}=2,92$, maka Ho diterima dan Ha ditolak artinya secara simultan variabel bebas tidak berdampak signifikan terhadap variabel terikatnya.

3. Uji Regresi Ganda

a. Diperoleh nilai $\mathrm{R}=0,43$ maka dapat dikatakan bahwa terdapat korelasi yang lemah antara variabel bebas dengan variabel terikat artinya apabila nilai korelasi variabel bebas naik maka variabel terikat juga akan meningkat sebab korelasinya bernilai positif.

b. Diperoleh nilai Adj. $\mathrm{R}=0,09$ atau hanya $9 \%$ nilai kontribusi variabel bebas terhadap variabel terikatnya, selebihnya dipengaruhi oleh faktor lain yang tidak diteliti pada studi ini.

c. Diperoleh nilai persamaan regresi: $Y=7,71 \mathrm{a}+0,02 \mathrm{X}_{1}+0,33 \mathrm{X}_{2}+0,26 \mathrm{X}_{3}$. Hal ini dapat dijelaskan bahwa kinerja guru akan semakin meningkat apabila motivasi berprestasi, kepuasan kerja, dan manajerial kepala sekolah naik.

Dari hasil di atas dapat didiskusikan beberapa yang terkait langsung dengan motivasi berprestasi, kepuasan kerja, dan manajerial kepala sekolah serta kinerja guru di SD Negeri 7 Idi.

\section{SIMPULAN}

Berdasarkan uji parsial diketahui bahwa masing-masing variabel bebas (motivasi berprestasi, kepuasan kerja, dan manajerial kepala sekolah) berdampak positif terhadap variabel terikat (kinerja guru). Berdasarkan uji simultan, tidak ditemukan pengaruh dari variabel bebas (motivasi berprestasi, kepuasan kerja, dan manajerial kepala sekolah) terhadap variabel terikat (kinerja guru). Berdasarkan uji regresi ganda diperoleh hasil bahwa terdapat korelasi yang positif dari variabel bebas (motivasi berprestasi, kepuasan kerja, dan manajerial kepala sekolah) terhadap variabel terikat (kinerja guru). Apabila nilai korelasi setiap variabel bebas naik, maka akan mampu meningkatkan kinerja guru.

\section{DAFTAR PUSTAKA}

Bungin, B. (2013). Metodologi Penelitian Kuantitatif: Komunikasi, Ekonomi, dan Kebijakan Publik Serta Ilmu-Ilmu Sosial Lainnya. Surabaya: Penerbit Kencana.

Creswell, J. (2015). Riset Pendidikan: Perencanaa, Pelaksanaan, dan Evaluasi Riset Kualitatif dan Kuantitatif. Yogyakarta: Pustaka Pelajar.

Mangkunegara, A.P. (2009). Manajemen Sumber Daya Manusia Perusahaan. Bandung: Penerbit PT. Remaja Rosdakarya. Robbins, S.P. dan Timoty, A.J. (2008). Perilaku Organisasi. Jakarta: PT. Salemba Empat.

Sagala, S. (2011). Manajemen Strategik Dalam Peningkatan Mutu Pendidikan. Bandung: Penerbit Alfabeta.

Sarinah. (2017). Hubungan Motivasi Berprestasi dengan Prestasi Akademik pada Mahasiswa Fakultas Psikologi Universitas Prima Indonesia, Jurnal Diversita, 3 (1): 32-39.

Siregar, N. (2017). Hubungan Motivasi Berprestasi dengan Prestasi Akademik pada Mahasiswa Fakultas Psikologi Universitas Prima Indonesia, Jurnal Diversita, 3 (1): 40-47.

Siregar, B. \& Nurmaida, I.S. (2010), Pengaruh Motivasi Berprestasi dan Disiplin Kerja terhadap Kinerja Pegawai PDAM Tirtanadi Provinsi Sumatera Utara Cabang Medan Kota, Analitika: 2 (1): 18-26

Suharputra, U. (2013). Administrasi Pendidikan. Bandung: Penerbit PT. Refika Aditama.

Timpe, A.D. (2002). Kinerja. Diterjemahkan Oleh Sofyan Cikmat. Jakarta: Penerbit PT. Elex Media Komputindo.

Usman, H. (2011). Manajemen: Teori, Praktik, dan Riset Pendidikan. Jakarta: Penerbit Bumi Aksara. 